\title{
Knowledge and Compliance with Standard Precautions among Nursing Students in Mosul University
}

\author{
Nasir M. Younis, Mahmood M. Ahmed \& Razkair khalel \\ Clinical Nursing Sciences Department, College of Nursing, University of Mosul, Iraq \\ Clinical Nursing Sciences Department, College of Nursing, University of Mosul, Iraq \\ Ministry of Health, Department of Nineveh, Ibn_alther teaching hospital, Iraq
}

\begin{abstract}
:
Student nurses are often exposed to various infections during their clinical education. Knowledge and compliance with standard precautions is essential to prevent hospital associated infections and protect patients as well as medical workers from exposure to infectious agents. This study aims:- To assess the knowledge and degree of compliance regarding standard precautions among Nursing Students in Mosul University.Method:- Descriptive Correlational design was applied in the present study. Random sample consist of (158) students' nurses (Male and Female) were studied in College of Nursing _ University of Mosul. Data were collected over a period of one month from first February 2014 to first March 2014.Results:- The study indicated that nursing students Knowledge and Compliance with Standard Precautions were high and there is a significant relationship between nurses Knowledge and Compliance of Standard Precautions.Conclusion and Recommendation:-As a results of this investigation it was concluted that the level of knowledge and compliance of standard precautions among the nursing student is rather high and teaching must be strengthened, particularly with respect to the concepts of nosocomial infection and hand hygiene where students scored less and the Periodic and continuous education program for nursing students about nosocomial infection, and standard precautions as well as further and nation-wide studies can be conducted on a large sample size of nursing student for include all colleges of nursing in Ira.
\end{abstract}

Keywords: Knowledge, Compliance, Standard Precautions, Nursing students.

\section{Introduction :}

Health care workers (HCWs) are at risk of various occupational hazards in the hospital, including exposure to bloodborne infections such as HIV and hepatitis $\mathrm{B}$ and $\mathrm{C}$ virus (HBV and $\mathrm{HCV}$ ) infection from sharps injuries and contact with body fluids. (Afitap,2008).Developing countries, which account for the highest prevalence of HIV-infected patients in the world, also record the highest rate of needle-stick injuries(Pruss-Ustun,2003). The World Health Organization (WHO,2002) estimates about $2.5 \%$ of HIV cases among HCWs and $40 \%$ of hepatitis B and $\mathrm{C}$ cases among HCWs worldwide are the result of these exposures. Nurses in particular are often exposed to various infections during the course of carrying out their nursing activities (Kosgeroglu et al,2004)Nursing students are also at risk of such infections and injuries due to accidental contamination during their practical occupational exposure. Exposure to infectious material can be minimized by adherence to standard precautions which are designed to reduce the risk of acquiring occupational infection from both known and unexpected sources in the healthcare setting(Siegel et al,2007) The standard precautions, proposed by the United States Centers for Disease Control and Prevention (CDC,2009) are guidelines for reducing the risk of transmission of blood-borne and other pathogens in hospitals. Standard or universal precautions are a set of measures formulated to prevent transmission of bloodborne pathogens when providing health care. Since identification of patients infected with these pathogens cannot be reliably made by medical history and physical examination, the Centers for Disease Control (CDC) has recommended that standard precautions be used on all patients, regardless of knowledge about their infection status (Chan, 2002).Data from a study in Sweden(Lymer,et.al 1997) showed that the majority of reported cases of occupational blood exposure were among nurses and a minority were among physicians. Other data revealed that nurses are the staff most frequently involved in occupationally acquired HIV infection (CDC,2002). Nurses are faced with professional hazards such as needle-stick injuries and blood borne infections in their day-today activities in the work place.Studies on standard precautions are increasing over the world, ( Jawaid,2009)( Sadoh,2006) however there has been limited attention paid to investigating nursing students' understanding and compliance regarding standard precautions within certain localities. Hence this study was conducted.

Aim of the study:- To assess the knowledge and compliance with standard precautions among nursing students in Mosul University in Iraq . 


\section{Methodology:}

Aim of the study and research Design:- To assess the knowledge and compliance with standard precautions among nursing students in Mosul University in Iraq .Descriptive Correlational design was applied in the present study.

Setting: Faculty of Nursing_ University of Mosul, Iraq.

Subject: (50)Male, (108) Female were students in College of Nursing.Total number of students in College(158) respondents,third year(66),fourth year(92).

Tools of data collection:- The researchers utilized the questionnaires developed by (Labrague et al 2012). consisting of three parts: Part 1: The students' demographical data including: The age, gender and marital status, Part 11: Questions were based on the basic concepts, content, and activity requirements of the standard precautions, covering 19 items, with possible responses of (Yes) and (No). 'Yes' is given a value of 1 point, and 'no' with 0 points; the maximum possible score is 19 . The higher the score, the greater the assumed knowledge about standard precautions the participant has. Result of test was interpreted as follows; $(16-19)$ as "Very Good Knowledge", (12 - 15) as "Good Knowledge", (8 $11)$ as "Fair Knowledge", and $(0-7)$ as "Poor Knowledge".Part 111: Compliance with standard precautions There was (17) compliance items with a scale of (0-4) points: $0=$ never, $1=$ seldom, $2=$ sometimes, 3 = usually, and $4=$ always, giving a score range of $0-68$. In determining the level of compliance, the following scaling was used; for High Compliance $=(3.51-4.00)$ Average Compliance $=$ $(2.51-3.50)$ Low Compliance $=(1.51-2.50)$ and Very Low Compliance $=(0-1.50)$. The higher the mean score, the better that person carries out the standard precautions.

Data analysis:- An interview technique method was used for data collection. The data from the questionnaire were coded and entered into a computerized data base and analyzed using SPSS, version 18. Frequencies, percentages, mean and median were used for analyzing the selected sociodemographic data and assessing level of knowledge and degree of compliance of student nurses. Pearson's correlation coefficient was utilized to test the relationship between the knowledge and compliance with standard precautions. A p-value of equal to or less than 0.05 was considered statistically significant.

Pilot study:- A pilot study was conducted for the determination of the validity and reliability of the questionnaire. The study was carried out for the period of 1th Jaunuary 2014 through 25th Jaunuary
2014, may selected (20) sample for pilot study. The study aimed to :-

1-Identify the barrier that may be encountered during data collection process .

2-Estimate the time required for data collection .

3-Determine the reliability of the questionnaire .

4-Obtain the clarity and the content adequacy of the questionnaire .

Tools of Validity and Reliability:- Content validity was determined by presenting the questionnaire to a panel of (12) experts who were specialists in Community Medicine, Community Health Nursing, Adults, Psychology, Sociology and Statistics. These experts were asked to review the questionnaire for content clarity, relevancy and adequacy. Their responses indicated that minor changes should be performed on few items. All modifications were made relative to their recommendations. The Reliability of the study Internal consistency of the questionnair was assessed by calculating Cronbach's Coefficient alpha. For this study the internal consistency for questionnair was (0.86).

Methods of Data Collection:-Data were collected through the use of the constructed questionnaire and the interview technique as a means of such collection, the period of the study was from first February 2014 to first March 2014.

Ethical considaration:- Mosul University of faculty Nursing Sciences Research Ethics Board approved ethical consideration for current study (Number: 91/d/130/169, in 2013/25/12). Meanwhile participants were asked to sign a consent form and were informed that withdrawal of the study at any time was possible. 


\section{Results :}

Table (1) : Demographic characteristics of the study subjects $(\mathrm{N}=158)$.

\begin{tabular}{|l|c|c|c|}
\hline \multicolumn{1}{|c|}{ Variable } & Number & Percentage(\%) \\
\hline Age & $20-23$ years & 136 & $\mathbf{8 6 . 1}$ \\
\hline & $23-25$ years & 22 & 13.9 \\
\hline Gender & Male & 50 & 31.6 \\
\hline \multicolumn{5}{|c|}{108} \\
\hline Marital status & Female & 139 & $\mathbf{6 8 . 4}$ \\
\hline \multicolumn{5}{|c|}{19} \\
\hline Level & Single & 66 & 12 \\
\hline \multicolumn{5}{|c|}{ Married } & 92 & 41.77 \\
\hline & Third & 158 & 100 \\
\hline
\end{tabular}

Table (2) : Responses to Questions Regarding Knowledge on Standard Precautions.

\begin{tabular}{|c|c|c|c|}
\hline Statements & $\begin{array}{l}\text { Correct } \\
\text { Answer }\end{array}$ & Frequency & Percentage \\
\hline \multicolumn{4}{|l|}{ 1. Nosocomial infection... } \\
\hline $\begin{array}{l}\text { a. The environment (air, water, inert surfaces) is the major } \\
\text { source of bacteria responsible for nosocomial infection. }\end{array}$ & No & 23 & 14.6 \\
\hline $\begin{array}{l}\text { b. Advanced age or very young age increases the risk of } \\
\text { nosocomial infection. }\end{array}$ & Yes & 138 & 87.3 \\
\hline $\begin{array}{l}\text { c. Invasive procedures increase the risk of nosocomial } \\
\text { infection. }\end{array}$ & Yes & 44 & 27.8 \\
\hline \multicolumn{4}{|l|}{ 2. Precaution standards... } \\
\hline a. Include the recommendations to protect only the patients & No & 120 & 75.9 \\
\hline $\begin{array}{l}\text { b. Include the recommendations to protect the patients and the } \\
\text { healthcare workers. }\end{array}$ & Yes & 145 & 91.8 \\
\hline c. Apply for all the patients. & Yes & 148 & 93.7 \\
\hline $\begin{array}{l}\text { d. Apply for only healthcare workers who have contact with } \\
\text { body fluid. }\end{array}$ & No & 124 & 78.5 \\
\hline
\end{tabular}

Table (3) : Responses to Questions Regarding Knowledge on Standard Precautions.

\begin{tabular}{|c|c|c|c|}
\hline Statements & $\begin{array}{l}\text { Correct } \\
\text { Answer }\end{array}$ & Frequency & Percentage \\
\hline \multicolumn{4}{|l|}{ 1. When is hand hygiene recommended? } \\
\hline a. Before or after a contact with (or care of) a patient. & No & 70 & 44.3 \\
\hline b. Between patient contacts. & Yes & 124 & 78.5 \\
\hline c. After the removal of gloves. & Yes & 120 & 75.9 \\
\hline \multicolumn{4}{|l|}{ 2. The standard precautions recommend use of gloves. } \\
\hline a. For each procedure. & No & 37 & 23.4 \\
\hline b. When there is a risk of contact with the blood or body fluid. & Yes & 129 & 81.6 \\
\hline c. When there is a risk of a cut. & Yes & 134 & 84.8 \\
\hline d. When healthcare workers have a cutaneous lesion. & Yes & 133 & 84.2 \\
\hline
\end{tabular}




\begin{tabular}{|l|c|c|c|}
\hline \multicolumn{1}{|c|}{ Statements } & $\begin{array}{c}\text { Correct } \\
\text { Answer }\end{array}$ & Frequency & Percentage \\
\hline 3. When there is a risk of splashes or spray of blood and body fluids, the healthcare workers must wear. \\
\hline a. Only mask. & No & 133 & 84.2 \\
\hline b. Only eye protection. & No & 140 & 88.6 \\
\hline c. Only a gown. & No & 133 & 84.2 \\
\hline d. Mask, goggles, and gown. & Yes & 148 & 93.7 \\
\hline
\end{tabular}

Table (4) : Knowledge of Student Nurses on Standard Precautions.

\begin{tabular}{|l|c|c|c|}
\hline & Score Range & Frequency (N=158) & Percentage (\%) \\
\hline Very good & $(16-19)$ & 40 & 25.32 \\
\hline Good & $(12-15)$ & 92 & 58.23 \\
\hline Accepted & $(8-11)$ & 24 & 15.18 \\
\hline Poor & $(0-7)$ & 2 & 1.27 \\
\hline Average Score & & 13.81 & $100 \%$ \\
\hline
\end{tabular}

Table (5) : Compliance with Standard Precautions(hand washing)

\begin{tabular}{|l|c|c|c|c|c|c|}
\hline \multirow{2}{*}{ Compliance Activity } & \multicolumn{5}{c|}{ Degree of Compliance } \\
\cline { 2 - 7 } & $\begin{array}{c}\text { Always } \\
(\mathbf{n}) \%\end{array}$ & $\begin{array}{c}\text { Usually } \\
(\mathbf{n}) \%\end{array}$ & $\begin{array}{c}\text { Sometimes } \\
(\mathbf{n}) \%\end{array}$ & $\begin{array}{c}\text { Seldom } \\
(\mathbf{n}) \%\end{array}$ & $\begin{array}{c}\text { Never } \\
(\mathbf{n}) \%\end{array}$ & $\begin{array}{c}\text { Total } \\
\text { Mean }\end{array}$ \\
\hline $\begin{array}{l}\text { 1-Washes hands when comes in } \\
\text { contact with different patients. }\end{array}$ & $106(67.1)$ & $27(17.1)$ & $17(10.8)$ & $5(3.2)$ & $3(1.9)$ & 3.44 \\
\hline $\begin{array}{l}\text { 2-Washes hands after taking off } \\
\text { the gloves. }\end{array}$ & $81(51.3)$ & $29(18.4)$ & $35(22.2)$ & $10(6.3)$ & $3(1.9)$ & 3.10 \\
\hline $\begin{array}{l}\text { 3-Washes hands immediately } \\
\text { after contacting any blood, body } \\
\text { fluid, secretion, excretion and } \\
\text { dirty substances. }\end{array}$ & $142(89.9)$ & $8(5.1)$ & $4(2.5)$ & $2(1.3)$ & $2(1.3)$ & 3.81 \\
\hline
\end{tabular}

Table 6. Compliance with Standard Precautions(Wears gloves)

\begin{tabular}{|l|c|c|c|c|c|c|}
\hline \multirow{2}{*}{ Compliance Activity } & \multicolumn{7}{|c|}{ Degree of Compliance } \\
\cline { 2 - 7 } & $\begin{array}{c}\text { Always } \\
(\mathbf{n}) \%\end{array}$ & $\begin{array}{c}\text { Usually } \\
(\mathbf{n}) \%\end{array}$ & $\begin{array}{c}\text { Sometimes } \\
(\mathbf{n}) \%\end{array}$ & $\begin{array}{c}\text { Seldom } \\
(\mathbf{n}) \%\end{array}$ & $\begin{array}{c}\text { Never } \\
\text { (n)\% }\end{array}$ & WM \\
\hline $\begin{array}{l}\text { 1-Wears gloves when drawing } \\
\text { blood samples. }\end{array}$ & $96(60.8)$ & $19(12)$ & $26(16.5)$ & $12(7.6)$ & $5(3.2)$ & 3.19 \\
\hline $\begin{array}{l}\text { 2-Wears gloves when disposing } \\
\text { stool and urine. }\end{array}$ & $119(75.3)$ & $12(7.6)$ & $13(8.2)$ & $5(3.2)$ & $9(5.7)$ & 3.43 \\
\hline $\begin{array}{l}\text { 3-Wears gloves when handling } \\
\text { impaired patient skin. }\end{array}$ & $77(48.7)$ & $29(18.4)$ & $43(27.2)$ & $5(3.2)$ & $4(2.5)$ & 3.07 \\
\hline $\begin{array}{l}\text { 4-Wears gloves when handling } \\
\text { patients' mucosa. }\end{array}$ & $125(79.1)$ & $17(10.8)$ & $13(8.2)$ & $1(0.6)$ & $2(1.3)$ & 3.65 \\
\hline $\begin{array}{l}\text { 5-Wears gloves when handling } \\
\text { saliva or sputum culture. }\end{array}$ & $129(81.6)$ & $12(7.6)$ & $13(8.2)$ & $2(1.3)$ & $2(1.3)$ & 3.67 \\
\hline $\begin{array}{l}\text { 6-Wears gloves when } \\
\text { performing parenteral injection } \\
\text { of medications. }\end{array}$ & $65(41.1)$ & $26(16.5)$ & $40(25.3)$ & $15(9.5)$ & $12(7.6)$ & 2.74 \\
\hline $\begin{array}{l}\text { 7-Wears gloves when dressing } \\
\text { wounds. }\end{array}$ & $122(77.2)$ & $21(13.3)$ & $12(7.6)$ & $1(0.6)$ & $2(1.3)$ & 3.64 \\
\hline
\end{tabular}




\begin{tabular}{|l|c|c|c|c|c|c|}
\hline \multirow{2}{*}{ Compliance Activity } & \multicolumn{7}{|c|}{ Degree of Compliance } \\
\cline { 2 - 7 } & $\begin{array}{c}\text { Always } \\
(\mathbf{n}) \%\end{array}$ & $\begin{array}{c}\text { Usually } \\
(\mathbf{n}) \%\end{array}$ & $\begin{array}{c}\text { Sometimes } \\
(\mathbf{n}) \%\end{array}$ & $\begin{array}{c}\text { Seldom } \\
(\mathbf{n}) \%\end{array}$ & $\begin{array}{c}\text { Never } \\
(\mathbf{n}) \%\end{array}$ & WM \\
\hline $\begin{array}{l}\text { 8-Wears gloves when cleaning } \\
\text { blood trace. }\end{array}$ & $113(71.5)$ & $23(14.6)$ & $17(10.8)$ & $2(1.3)$ & $3(1.9)$ & 3.52 \\
\hline $\begin{array}{l}\text { 9-Wears gloves when comes in } \\
\text { contact with blood. }\end{array}$ & $130(82.3)$ & $15(9.5)$ & $8(5.1)$ & $1(0.6)$ & $4(2.5)$ & 3.68 \\
\hline
\end{tabular}

Table 7. Compliance with Standard Precautions(wears protective).

\begin{tabular}{|c|c|c|c|c|c|c|}
\hline \multirow{2}{*}{ Compliance Activity } & \multicolumn{6}{|c|}{ Degree of Compliance } \\
\hline & $\begin{array}{l}\text { Always } \\
\text { (n)\% }\end{array}$ & $\begin{array}{c}\text { Usually } \\
\text { (n)\% }\end{array}$ & $\begin{array}{l}\text { Sometimes } \\
\text { (n) \% }\end{array}$ & $\begin{array}{c}\text { Seldom } \\
\text { (n)\% }\end{array}$ & $\begin{array}{l}\text { Never } \\
\text { (n)\% }\end{array}$ & $\begin{array}{l}\text { Total } \\
\text { Mean }\end{array}$ \\
\hline $\begin{array}{l}\text { 1-Wears mask when performing } \\
\text { operations/procedures that might } \\
\text { induce spraying of blood, body } \\
\text { fluid, secretions and excretions. }\end{array}$ & $129(81.6)$ & $16(10.1)$ & $6(3.8)$ & $3(1.9)$ & $4(2.5)$ & 3.66 \\
\hline $\begin{array}{l}\text { 2-Wears protective eye patch or } \\
\text { goggle when performing } \\
\text { operations/procedures that might } \\
\text { induce spraying of blood, body } \\
\text { fluid, secretions and excretions. }\end{array}$ & $89(56.3)$ & $29(18.4)$ & $24(15.2)$ & $9(5.7)$ & $7(4.4)$ & 3.16 \\
\hline $\begin{array}{l}\text { 3-Wears protective suit or gown } \\
\text { when performing } \\
\text { operations/procedures that might } \\
\text { induce spraying of blood, body } \\
\text { fluid, secretions and excretions. }\end{array}$ & 111(70.3) & $32(20.3)$ & $11(7.0)$ & $2(1.3)$ & $2(1.3)$ & 3.56 \\
\hline 4-Do not recap syringe after using. & $122(77.2)$ & $7(4.4)$ & $6(3.8)$ & $2(1.3)$ & $21(13.3)$ & 3.31 \\
\hline $\begin{array}{l}\text { 5-Disposes needles and blades in a } \\
\text { sharp disposal box or receptacle } \\
\text { after using. }\end{array}$ & 133(84.2) & 11(7) & 12(7.6) & $0(0)$ & $2(1.3)$ & 3.72 \\
\hline
\end{tabular}

Table 8: Summary of Compliance of Standard Precautions.

\begin{tabular}{|l|c|c|}
\hline \multicolumn{1}{|c|}{$\begin{array}{c}\text { Components of Standard } \\
\text { Precautions }\end{array}$} & Mean & Rank \\
\hline Use of Masks & 3.66 & 1 \\
\hline Use of Protective Suit & 3.56 & 2 \\
\hline Proper disposal of used needles & 3.51 & 3 \\
\hline Hand washing & 3.45 & 4 \\
\hline Use of Gloves & 3.39 & 5 \\
\hline Use of Eye goggles & 3.16 & 6 \\
\hline Grand Mean & \multicolumn{2}{|c|}{3.46} \\
\hline
\end{tabular}

Table 9: Correlation between Knowledge and Compliance of Standard Precautions.

\begin{tabular}{|l|c|c|}
\hline \multicolumn{1}{|c|}{ Variables } & r-value & p-value \\
\hline Knowledge and Compliance of Standard Precautions & 0.112 & 0.453 \\
\hline
\end{tabular}

*Significance level, $a=0.05$; two-tailed; $d f=156$; critical value $=2.00$ 
Table (1) : There were 158 respondents in the study. There were $50(31.6 \%)$ male and $108(68.4 \%)$ female respondents. Majority of the respondents or 136 $(86.1 \%)$ were within the age bracket of 20 to 22 years old with mean age of 21.5 years. Almost all of the respondents $139(88 \%)$ were single while only 19 (12\%) were married. Finally the Level of study the respondents $92(58.23)$ were fourth stage while in third stage 66(41.77).

Table (2) : presents the answers concerning the knowledge of respondents on Standard Precautions. Majority of the respondents $(87.3 \%)$ agreed that the advanced age or very young age increases the risk of nosocomial infection, while $(27.8 \%)$ believed that Invasive procedures increase the risk of nosocomial infection. As to the knowledge of the goals of standard precautions, $(91.8 \%)$ responded include recommendation to protect the patients and healthcare worker from nosocomial infection. while 93.7\% thought that it is applied for all patients.

Table (3) : shows that the knowledge on hand hygiene, $78.5 \%$ confirmed that hand hygiene Between patient contacts, while $(44.3 \%)$ reported that it is recommended before or after contact with a patient. All of the respondents (100\%) agreed with the use of gloves when there is a risk of contact with blood or body fluids, while $96.2 \%$ think that gloves should be used for all procedures.

Table (4) : presents the cumulative scores of the respondents on the questionnaires on standard precautions. Nearly half $(58.23 \%)$ of the respondents scored within the score range of 12 to 15 which is interpreted as "Good Knowledge", while 25.32\% scored within the score range of 16 to 19 which is interpreted as " Very Good Knowledge”. In general, student nurses possess "Good Knowledge" on standard precautions with total mean score of 13.81

Table (5) : depicts the information obtained from respondents regarding their compliance activities. As reflected on the table below, majority with standard percentage of the respondents $(89.9 \%)$ washes hand immediately after contacting any blood, body fluid, secretion, excretion and dirty substances, (67.1\%) washes hands when comes in contact with different patients,wihle $(51.3 \%$ ) Washes hands after taking of gloves .

Table (6) : shows that the wearing of gloves, vast majority of the respondents wears gloves when disposing stool and urine $(75.3 \%)$, when handling patient's mucosa $(79.1 \%)$, saliva and sputum culture $(81.6 \%)$, and when comes in contact with blood $(82.3 \%)$.

Table (7) : indicated that the majority of the respondents adheres to wearing of mask and protective suit or gown when performing procedures that might induce spraying of blood, body fluid, secretions and excretions with compliance rates of $81.6 \%$ and $70.3 \%$ however, a significant percentage of non compliance $(4.4 \%)$ with the use of protective eye patch and eye goggles were noted. As to proper care of used needles, $84.2 \%$ disposes needles and blades in a sharp disposal box or receptacle after using, and almost three fourths (77.2\%) do not recap syringe after using. In general, student nurses have a "High Compliance" of standard precautions with a grand mean of 3.48 .

Table (8) : shows the components of standard precautions. When items were grouped into the 6 components, a mean for all items in each component was calculated for each respondent. The overall means were then calculated on the basis of the respondents mean scores for each item. Data indicated that the use of mask has the highest degree of compliance with a weighted mean of 3.66 which is interpreted as "High Compliance". On the other hand, the use of eye goggles has the lowest degree of compliance with a weighted mean of 3.16 which is interpreted as "Average Compliance".

Table (9) : depicts the relationship between student nurses' knowledge and compliance of standard precautions. As seen gleaned on the table, the relationship between staff nurses' knowledge and compliance of standard precautions posted an r-value of 0.051 with a computed $p$-value of 0.453 which was lesser than its critical value of 2.00 at not significance level of 0.05 .

\section{Discussion:}

This investigation explored the knowledge and degree of compliance regarding standard precautions among nursing students in university of Mosul, Iraq. The study sample consisted of 158 student of nursing. Most of the subjects were females and nearly one third of them were males. Regarding their ages, most of the subjects were in the age group <25 years Table(1). Results of this study showed that knowledge about nosocomial infection was the lowest among the five components of standard precautions. Students did not know exactly what or who were the main sources of bacteria responsible for nosocomial infection since vast majority of them thought that the environment was the primary source of bacteria. table(2). The results indicated that student nurses were knowledge able concerning standard precautions. In Korea (Kim et al. 2001) also reported that knowledge of standard precautions was better among nursing students than among medical students. This is in complete disagreement with that of Bamigboye and Adesanya, 2006 study, where in only $46.2 \%$ of student nurses had very good knowledge.Studies among nursing population also 
showed similar result to this study. (Vaz et al 2010) also reported that $90.0 \%$ of nurses had knowledge of standard precautions.table(3) .The cause good knowledge of standard precautions among student nurses may be due to inclusion of the concepts of standard precautions in the college of nursing curriculum. (Sax et al2005) reported that lack of knowledge is the major reason for non adherence to standard and isolation precautions.This result disagrees with my study (Melo et al 2006) in Brazil, conducted studies among nurses and other clinicians regarding knowledge on aseptic technique and standard precautions found that only $75.6 \%$ understood the standard precautions as protective measures. In the study of (Luo et al 2010) in China about Factors impacting compliance with standard precaution in nursing found 1444 nurses, only half ( $\mathrm{n}$ $=722$ ) had knowledge of all the standard precautions, while (Abdulraheem et al 2012) in Nigeria observed that half $(50 \%)$ of the health workers had no knowledge of universal precautions Table(4).

On the other hand, the compliance with standard precautions is concerned, findings revealed that students had a high compliance during the training practical .This may be due to stringent monitoring done by the faculty relative to standard precaution practices during clinical rotation. Also they were able to monitor and follow up closely their student during the performance of standard precaution practices. Although majority of the students knew that mask, goggles and gown must be worn by the nurses when there is a risk of splashes or spray of blood and body fluids, surprisingly compliance with the use of protective eye patch or eye goggle was relatively low. Table(5). Table(6). The causes may be attributed to unavailability of personal protective equipments in every ward of the hospitals where they are rotated. This finding is similar with that of (Luo et al 2010) in China about Factors impacting compliance with standard precaution in nursing where they observed that the use of protective items such as eye shields, masks, and quarantine clothes among Chinese nurses had the lowest compliance. Table(7).

This results indicated that the significant association between knowledge and compliance with standard precautions. The results are in agreement with the study of (Kim and others 2001) who found that knowledge is correlated to performance of universal precautions. Table(9).

\section{Conclusions:}

The study concluded from this investigation that the level of knowledge and compliance of standard precautions among the nursing students is rather high

\section{recommendations:}

The study recommended that the Periodic and continuous education program for nursing students about nosocomial infection, and standard precautions and the essential compliance and standard precaution should be display in the form of posters or booklets in all health facilities as well as further and nation-wide studies can be conducted on a large sample size of nursing student for include all colleges of nursing in Iraq. and teaching must be strengthened, particularly with respect to the concepts of nosocomial infection and hand hygiene where students scored less.

\section{Reference:}

1. Abdulraheem. I. S. Amodu. M. O. Saka. M. J. Bolarinwa. O. A. \& Uthman.M. M. (2012). Knowledge, Awareness and Compliance with Standard Precautions among Health Workers in North Eastearn Nigeria. Journal Community Med Health Edu, 3 (2), 131-136.

2. Afitap. Ö.A.(2008). Conditions in which nurses are exposed to the hepatitis viruses and precautions taken for prevention.Australlian jouurnal of advanced nursing (30)1.33-41.

3. Bamigboye. A. P..\& Adesanya. A. T. (2006). Knowledge and Practice of Universal Precautions among Qualifying Medical and Nursing Students: A Case of Obafemi Awolowo University Teaching Hospitals Complex, ILEIFE. Research Journal of Medicine and Medical Sciences, 1(3), 112-116.

4. Centers for Disease Control and Prevention. Surveillance of healthcare personnel with HIV/AIDS, as of December Available at: http://www.cdc.gov/ncidod/dhqp/bp_hiv_hp_wit h.html (accessed April 2009).

5. Centers for Diseases Control and Preventtion. HIV/AIDS surveillance report, 2002, 5(3):13.

6. Chan. R. Y.(2002) .Nurses' knowledge of and compliance with 8 . universal precautions in an acute care hospital. International Journal of Nursing Studies. 39:157-163.

7. Jawaid. M. Iqbal. M.Shahbaz. S. (2009) Compliance with standard precautions: a long way ahead. Journal of Public Health , 38:85-8.

8. Kim. K. M. Kim. M. A. Chung. Y. S. \& Kim. N. C. (2001). Knowledge and performance of the universal precautions by nursing and medical students in Korea. Am J Infect Control, 29, 295300. http://dx.doi.org/10.1067/mic.2001.114837.

9. Kosgeroglu, N., Ayranci, U., Vardareli, E., \&Dincer, S. (2004). Occupational exposure to hepatitis infection among Turkish nurses: frequency of needle exposure, sharps injuries and 
vaccination. Epidemiol Infect, 132(1), 27-33. http://dx.doi.org/10.1017/S0950268803001407.

10. Labrague.L.J. Rosales.R.A. Marical. M.Y.(2012).Knowledeg of and Compliance with Standard Precautions among Student Nurses.International Journal of Advanced Nursing Studies, 1(2),84-97.

11. Luo. Y. He. G.P. Zhou.J.W. \& Luo. Y. (2010). Factors impacting compliance with standard precaution in nursing, china. International Journal of Infectious Diseases, 14(12), e1106e1114. http://dx.doi.org/10.1016/j.ijid.2009.03.037.

12. Lymer. U. Schutz. A. and Isaksson. B.(1997) Adescriptivd study of blood exosure incidents among healthcare workers in a university hospital in Sweden .J Hos infe. 35:223-5.

13. Melo. D.S. Silva. E. Souza. A.C. Tipple. A.F. Neves. Z.C. and Pereira. M.S. (2006) Nurses' understanding of standard precautions at a public hospital in Goiania - GO, Brazil. Rev Lat Am Enfermagem, 14:720-7.

14. Pruss.U.A. Rapiti. E. Hutin. Y. 4. Sharps injuries: global burden of disease from sharps injuries to health-care workers. Geneva, World Health Organization, 2003.

15. Sadoh. W. E. Fawole. A. O. Sadoh. A. E. Oladimeji.A. O. \&Sotiloye. O. S. (2006) Practice of universal precautions among healthcare workers. J Natl Med Assoc, 98, 722726.

16. Sax. H. Perneger. T. Hugonnet. S. Herrault. P. Chraiti. M. N. \& Pittet. D. (2005). Knowledge of standard and isolation precautions in a large teaching hospital. Infect Control Hosp Epidemiol, 26(3), 298-304. http://dx.doi.org/10.1086/502543.

17. Siegel. J. D. Rhinehart. E. Jackson. M. \&Chiarello. L. (2007). Healthcare Infection Control Practices Advisory Committee. Guideline for isolation precautions: preventing transmission of infectious agents in healthcare settings. Centers for Disease Control.

18. Vaz. K. McGrowder. D. Crawford. T. Alexander-Lindo.R. L. \& Irving, R. (2010). Prevalence of injuries and reporting of accidents among Health Care Workers at the University Hospital of the West Indies. Int J Occup Med Environ Health, 23, 133-143. http://dx.doi.org/10.2478/v10001-010-0016-5.

19. World Health Organization (WHO). The word health report 2002: reducing risks,promoting health life. World Health Organization, Geneva. 